\title{
Penyelesaian Sengketa Waris Berbasis Kearifan Lokal di Desa Gayasan A, Kecamatan Jenggawah, Kabupaten Jember, Provinsi Jawa Timur
}

\author{
Erfina Fuadatul Khilmi, Arvina Hafidzah \\ Fakultas Syariah dan Hukum, IAIN Jember
}

\begin{abstract}
ABSTRAK
Perbedaan dalam memahami pola pembagian hak waris berpotensi menimbulkan sengketa yang mempengaruhi hubungan keluarga menjadi semakin luntur dan berimplikasi pada konflik yang tidak berujung antar keluarga satu dengan lainnya. Tujuan penelitian ini adalah memahami implementasi penyelesaian sengketa waris dengan menggunakan sarana kearifan lokal setempat sebagai metode alternatif dalam mencapai keseimbangan dan harmoni masyarakat yang masih menganggap tabu tindakan penyelesaian melalui jalur pengadilan. Hasil penelitian ini menunjukkan bahwa faktor yang mempengaruhi adanya perbedaan dalam pembagian waris di Desa Gayasan A Kecamatan Jenggawah Kabupaten Jember adalah tidak adanya komunikasi antar pewaris dan ahli waris atau dikenal istilah keluarga debik kek lopaen dan penilaian masyarakat terhadap ahli waris sangat menentukan terkait pembagian hak waris, sehingga diperlukan kearifan lokal yang menjadi sarana strategis dalam menyelesaikan sengketa melalui perembugen dengan diskusi internal keluarga dan mediasi kepala adat serta pengucilan (tak diajepi). Data dikumpulkan melalui kombinasi antara studi pustaka dengan studi lapang dengan cara melakukan pengamatan, wawancara dan angket. Metode penelitian yang digunakan dalam penelitian ini adalah sosiologi hukum dengan pendekatan masalah pada hukum adat tidak tertulis yang lebih memberlakukan hukum yang hidup di masyarakat Desa Gayasan A sebagai fakta sosial yang dibangun dari sistem nilai masyarakatnya dengan didukung oleh pendekatan teori (teori approach).
\end{abstract}

Keywords: Sengketa Waris, Kearifan Lokal, Masyarakat Desa Gayasan A

\section{PENDAHULUAN}

Adanya perkembangan interaksi dalam sebuah adat dan budaya yang berbeda di suatu daerah cenderung memberikan pola pikir terhadap sikap dan tindakan yang menghasilkan suatu sistem pengetahuan kolektif di tengah-tengah masyarakat. Seperti halnya dengan masyarakat di Desa Gayasan A, Kecamatan Jenggawah, Kabupaten Jember. Dengan adat istiadat suku Madura yang kental serta taatnya masyarakat dengan agama islam yang dianut menjadi faktor dari bagaimana cara bersikap dan bertindak dalam menyelesaikan masalah kehidupan secara bijaksana, salah satunya mengenai sistem pembagian waris yang dilakukan menurut pluralisme 
hukum adat dan hukum islam dalam posisi yang sederajat dan terintegrasi dalam sistem hukum yang berlaku di masyarakat Dikatakan demikian, karena sistem pembagian warisan biasanya tergantung dari kekerabatan ataupun sifat individual satu keluarga. Terkadang melihat dari perannya sebagai kepala keluarga, pihak lelaki mendapatkan bagian yang lebih banyak atau 2:1 dengan pihak perempuan. Namun tidak dapat dipungkiri, adanya faktor kedekatan yang menjadi salah satu pengaruh dalam pembagian waris bisa saja dibagikan merata 1:1 maupun pihak perempuan yang mendapatkan lebih banyak.

Hal tersebut tentunya berbeda dengan konsep yang dianut Hazairin mengenai hukum waris adat yang mempunyai coraknya tersendiri dari alam pikiran masyarakat yang tradisional dengan bentuk sistem kekerabatan partrilineal, matrilineal maupun bilateral. ${ }^{1}$ Perbedaan dalam memahami sistem kekerabatan terhadap pola pembagian waris inilah yang rentan akan konflik dalam suatu keluarga karena pembagian hak waris yang tidak dilakukan secara merata. Konflik inilah yang menyebabkan perpecahan pendapat dalam hubungan kekeluargaan, sehingga berpotensi terjadi sengketa yang nantinya akan berujung penyelesaian di jalur litigasi. Tindakan penyelesaian ini tentu mengeluarkan tenaga, waktu dan biaya yang tidak sedikit. Selain itu, masyarakat di Desa Gayasan A terkesan memandang persengketaan yang diselesaikan di pengadilan menjadi hal yang tabu dan tanda keretakan hubungan kekeluargaan pihak yang bersengketa. Mereka menganggap persengketaan yang sudah dilakukan melalui jalan mediasi bila tetap dipaksakan untuk diteruskan melalui jalur hukum menjadi bentuk lunturnya rasa kekeluargaan pihak bersengketa yang tentu akan menjadi pembicaraan masyarakat, hal ini mengingat dekatnya hubungan kekeluargaan antara satu orang dengan lainnya. ${ }^{2}$

Berdasarkan uraian diatas, salah satu alternatif yang digunakan masyarakat Gayasan A dalam menyelesaikan sengketa waris adalah dengan menggunakan sarana kearifan lokal masyarakat setempat sebagai metode penyelesaian yang cenderung menonjolkan sifat-sifat lokal dengan menjunjung tinggi prinsip-prinsip moralitas dalam suatu kerangka karakteristik dari komunitas lokal tersebut untuk mencapai keseimbangan terhadap pengelolaan penyelesaian sengketa waris. Hal tersebut sejalan dengan pendapat Suhartini yang mendefinisikan kearifan lokal sebagai tata nilai kehidupan yang tidak hanya dalam bentuk religi, tetapi juga budaya dan adat istiadat secara turun temurun yang dianggap memiliki kearifan untuk beradaptasi dengan lingkungan masyarakat setempat. ${ }^{3}$

Oleh karena itu, isu hukum yang ditulis dalam penelitian ini adalah penyelesaian sengketa waris dengan corak pluralisme hukum berbasis kearifan lokal. Hal tersebut menarik untuk diteliti karena pelestarian terhadap kearifan lokal

1. Yulia, Buku Ajar Hukum Adat, (Lhokseumawe: Unimal Press,2016), hlm.82

${ }^{2}$ Wawancara bersama saudara Mukhtar Hafidz, salah satu masyarakat hukum adat di Desa Gayasan A, Kecamatan Jenggawah, Kabupaten Jember.

${ }^{3}$. Dikutip oleh Agus Wibowo dan Gunawan, Pendidikan Karakter Berbasis Kearifan Lokal, (Yogyakarta: Pustaka Pelajar, 2015), hlm 17. 
merupakan sarana lokalitas yang efektif dalam mencapai keseimbangan dan harmoni terhadap penyelesaian sengketa yang terjadi di masyarakat.

\section{Faktor-Faktor Yang Mempengaruhi Perbedaan Dalam Pembagian Harta Waris Pada} Masyarakat Desa Gayasan A, Kecamatan Jenggawah, Kabupaten Jember

Masyarakat Desa Gayasan A, Kecamatan Jenggawah, Kabupaten Jember secara turun temurun tinggal di timur Gunung jenggawah serta dikelilingi oleh persawahan dan ladang dengan adat Madura yang kental berpadu dengan hukum islam. Masyarakat di Desa ini, walaupun merupakan masyarakat "Madura swasta" atau masyarakat adat Madura yang tinggal di luar Pulau Madura tetaplah dapat dikatakan sebagai bagian dari kesatuan adat Madura itu sendiri. Dalam kesehariannya, masyarakat ini telah menerapkan pluralisme hukum yang berbasis pada adat istiadat dan hukum islam. Secara umum pluralisme hukum adalah situasi dimana terdapat dua atau lebih sistem hukum yang dipraktikkan dalam suatu kehidupan sosial. ${ }^{4}$ Adanya pluralisme hukum waris adat sendiri sebenarnya terpengaruh oleh teori receptio contorario yakni teori bantahan atas teori reciptie yang menjelaskan bahwa hukum islam masuk setelah adanya hukum adat, oleh karena itu hukum islam harus mengikuti hukum adat setempat. Teori milik Snouck Hugronje dan Van Vollenhoven ini sendiri merupakan bantahan teori yang dicetuskan Van De Berg yakni teori reception in complexu yang menjelaskan bahwa hukum adat mengikuti keberadaan hukum islam yang dipeluk oleh suatu masyarakat hukum adat. Teori reciptie ini berdasarkan Snouck Hurgronje bertujuan agar orang-orang pribumi saat itu tidak memegang teguh ajaran agama islam, sebab bila ajaran islam dipegang teguh dalam suatu masyarakat dikhawatirkan sulitnya pengaruh budaya barat untuk merasuk dalam sendi kehidupan masyarakat hukum adat. ${ }^{5}$ Teori reciptie dibantah secara gamblang oleh pakar hukum adat asal Indonesia yakni Prof. Hazairin dan Prof. Sayuti Thalib, bahkan teori ini dianggap Prof. Hazairin sebagai teori iblis sebab selain bertentangan dengan Undang-Undang Dasar 1945, teori ini juga dianggap telah bertentangan dengan al-Quran dan Sunnah. ${ }^{6}$

Yahya Harahap dalam bukunya menjelaskan makna teori reception contorario yakni hukum adat haruslah menyesuaikan kepada hukum islam, atau lebih tepatnya hukum adat yang ada haruslah tidak bertentangan dengan hukum islam yang dianut masyarakatnya. Jika norma hukum adat yang berlaku tidak sesuai atau bahkan bertentangan perlakuannya dengan hukum islam, maka norma hukum adat tersebut haruslah dijauhi penggunaannya. ${ }^{7}$ Teori ini dapat dikatakan sebagai teori yang

\footnotetext{
${ }^{4}$ Hendra Nurtcahyo, Legal Standing Kesatuan Masyarakat Hukum Adat, (Jakarta: Salemba Humanika, 2010), hlm. 15.

${ }^{5}$ Dikutip dalam Irmawati, “Teori Belah Bambu Syahrizal Abbas: antara Teori Reception in Complexeu, Teori Reciptie, dan Teori Receptio Contrario" (2017) Vol 2 No 2, Ar Raniry, hlm.180.

${ }^{6}$ Sovia Hasanah, “Arti Teori eceptio A Contrario" 2018 < www.hukumonline.com > diakses pada tanggal 24 Agustus 2020.

${ }^{7}$ Yahya Harahap, Kedudukan Janda, Duda, dan Anak Angkat dalam Hukum Adat, (Bandung: PT. Citra Aditya Bakti, 1993), hlm. 62.
} 
menjadi awal bangkitnya politik hukum islam di Indonesia. ${ }^{8}$ Teori reception contorario secara konsep sudah sesuai dengan penuturan M.B Hoeker bahwa baik dalam hukum adat maupun hukum islam ada hukum yang saling menyisihkan, keduanya berlaku dan menciptakan daya tarik sederajat yang berlaku dan membentuk pola khusus di tengah masyarakat, keduanya walaupun berjalan beriringan tidak dapat dipungkiri di suatu saat tertentu akan menimbulkan konflik. ${ }^{9}$ Teori reception contarario inilah yang nantinya akan mempengaruhi sistem pembagian waris di desa Gayasan A, Kecamatan Jenggawah Kabupaten Jember dengan mengintegrasikan hukum islam dan hukum adat secara beriringan, terutama terkait persoalan waris dalam konteks penelitian ini.

Mengenai pembagian waris di Desa Gayasan A, lebih mengarah kepada sistem parental atau bilateral (garis keturunan bapak dan ibu) yakni sistem pembagian waris yang memberikan hak yang sama untuk mendapatkan warisan antara pihak laki-laki dan anak perempuan. ${ }^{10}$ namun dalam hal pembagian keduanya tidaklah sama, artinya pembagian waris tidak hanya didasarkan pada hukum islam yakni 2:1 namun terkadang menerapkan prinsip 1:1 dalam kekerabatan. ${ }^{11}$ Sedangkan untuk pembagian rumah, tanah, dan harta tidak bergerak lainnya di Desa ini biasanya akan ada perembukan dari pihak-pihak ahli waris. Terkadang pihak laki-laki yang mendapatkan, tapi tidak jarang juga pihak perempuan yang mendapatkan hak atas tanah atau rumah yang di wariskan.

Dalam konteks pembagian waris yang di anut Desa Gayasan A adalah bersifat individual dalam suatu kekerabatan karena lebih diutamakan pada kesepakatan para ahli waris. Meskipun demikian, ada mayoritas warga yang berpegang teguh pada hukum islam dalam pembagian waris, dimana pihak laki-laki mendapatkan hak waris dua kali lipat dari perempuan. Hal ini dikarenakan faktor pihak lelaki di desa tersebut berperan sebagai kepala keluarga, sedangkan pihak perempuan mengikuti suami atau bahkan tinggal dengan mertua. Selain itu, tokoh agama juga berperan penting dalam hal pembagaian waris, sehingga sistem waris yang digunakan juga berdasarkan hukum islam.

Ada beberapa faktor yang mempengaruhi adanya perbedaan dalam pembagian waris di Desa tersebut. yakni:

1. Terjalin atau tidaknya komunikasi antar pewaris dan ahli waris. Dijelaskan seperti ini, misal ada seseorang merantau di luar desa kemudian jarang menghubungi ataupun tidak dihubungi sama sekali maka istilah keluarga debik kek lopaen akan dijadikan acuan dalam pengurangan jumlah waris

\footnotetext{
${ }^{8}$ Adelina Nasution, "Pluralisme Hukum Waris di Indonesia" (2018) Al-Qadha 5:1, hlm. 22-23.

${ }^{9}$ M.B Houker, Legal Pluralisme: an Introduction to Colonial and Neocolonial Laws, (Offord: University Press, 1975), hlm. 25.

${ }^{10}$ Nur Nafa Maulida Atlanta,dkk, "Studi Komparasi Hak Waris dalam Hukum Adat dan Islam di Masyarakat Madura Pernatauan Desa Jelbuk, Kecamatan Jelbuk, Kabupaten Jember”, Vol.5 Issue 3 (2018) Lentera Hukum, Universitas Jember, hlm.415.

${ }^{11}$ Soerjono Soekanto, Hukum Adat Indonesia, (Jakarta: PT Raja Grafindo, 2013),hlm.263.
} 
ataupun bahkan dasar untuk tidak memberikan warisan sama sekali. Sementara waalupun merupakan anak angkat, jika memiliki hubungan yang baik dengan pewaris mungkin saja akan mendapatkan hak waris yang lebih besar daripada anak kandung.

2. Faktor Lingkungan, bila warga sekitar merasa ia tidak pantas meminta hak waris kepada orang tuanya yang biasanya dilihat memiliki kekurangan dalam hal harta maka bila si anak tetap meminta maka akan ada sanksi pengucilan oleh masyarakat. Kemudian juga, bila masyarakat merasa perlakuan seseorang buruk di mata mereka, maka pewaris mungkin saja mengurangi hak waris orang tersebut mengingat pembicaraan yang dilakukan oleh masyarakat mungkin dapat menjelekkan nama keluarga.

3. Pihak perantau yang kembali ke kampung halamannya untuk mengurus pemakaman dan mendapati dirinya mendapatkan bagian lebih sedikit atau bahkan tidak sama sekali membuatnya merasa tidak adil dan menuntut adanya perhitungan kembali. ${ }^{12}$

Dari ketiga faktor diatas dapat kita lihat bahwa pembagian harta waris lebih menekankan pada hubungan kekeluargaan daripada status "kandung" dan "angkat". Sebab kedekatan emosional lebih diperhatikan daripada melihat status anak tersebut, karenanya hukum waris adat di desa Gayasan A tidak membedakan hak antara anak kandung dan anak angkat dalam hal pembagian waris. Pembagian harta waris kepada anak angkat sendiri sudah termaktub dalam putusan Raad Justitie tanggal 24 Mei 1990 yang memperbolehkan anak angkat untuk mendapatkan harta waris orang tuanya, sementara untuk harta pusaka atau harta yang diurunkan ke kerabatan kandung tidak diperbolehkan. ${ }^{13}$ Hal ini menjadi salah satu alasan adanya perdebatan yang akhirnya menimbulkan sebuah persengketaan diantara kedua belah pihak. Adanya rasa tidak adil yang dirasakan oleh anak kandung dengan hak yang diberikan oleh anak angkat menjadi salah satu pemicu persengketaan waris

Sengketa waris yang terjadi ini tentu saja berdampak dalam kehidupan suatu kekerabatan, entah itu melunturkan rasa kekeluargaan yang dapat mengakibatkan keretakan ataupun dapat menjelekkan nama keluarga di mata masyarakat. Hal-hal inilah yang menunjukkan bahwa persoalan pembagian waris tidak bisa dianggap sebagai perkara yang mudah dan sederhana untuk diselesaikan, sebagaimana di kemukakan oleh Asmaul husni Purba dalam skripsinya yang menuturkan bahwa persengketaan waris bukanlah hal yang dapat dianggap remeh karena bisa membawa efek buruk berkelanjutan dalam sebuah kekerabatan yang kemungkinan terburuk bahkan dapat memutus hubungan kekeluargaan antara kedua belah pihak yang bersengketa. ${ }^{14}$ Penuturan ini pun didukung oleh hasil wawancara bersama saudara

\footnotetext{
${ }^{12}$ Informasi di dapatkan melalui wawancara dengan salah satu warga yakni Mukhtar Hafidz.

${ }^{13}$ Putusan M.A. tanggal 18 Maret 1959 Reg. No. 37 K/SIP/1959)

${ }^{14}$ Asmaul Husni Purba "Faktor-Faktor Masyrakat Menyelesaikan Sengketa Warisan ke MUI Kota Medan" (2018) Skripsi Fakultas Syariah dan Hukum Universitas Agama Islam Negeri (UIN) Sumatera Utara, hlm.35.
} 
Mukhtar Hafidz selaku masyarakat hukum adat yang tinggal di desa Gayasan A, Kecamatan Jenggawah, Kabupaten Jember yang menjelaskan bahwa persengketaan waris walaupun merupakan hal yang lumrah terjadi akibat adanya sistem pewarisan yang individual di setiap kekerabatan serta perbedaan pandangan dalam menentukan pembagian waris akibat adanya pluralisme hukum namun juga tidak dapat dipungkiri merupakan permasalahan kompleks dan sensitif karena selain menyangkut soal kekerabatan, persengketaan ini juga menyangkut soal harta yang menjadi sumber pemenuhan kebutuhan sehari-hari ahli waris. ${ }^{15}$

Pembagian waris yang tidak diselesaikan secara benar dan bijaksana, maka berimplikasi terhadap kekerabatan antar keluarga, baik itu berakhir pada keretakan maupun dapat menjelekkan nama keluarga di mata masyarakat. Oleh karena itu, diperlukan sarana alternatif yang mampu memberikan keseimbangan dan harmoni dalam menyelesaikan persengketaan tersebut

\section{Penyelesaian Sengketa Waris Berbasis Kearifan Lokal Di Desa Gayasan A, Kecamatan Jenggawah, Kabupaten Jember}

Seringkali persengketaan yang sering memecah suatu kekerabatan adalah sengketa yang berkaitan dengan warisan. Data menunjukkan bahwa Sebanyak $63.8 \%$ koresponden acak dari 47 orang yang didapat dari masyarakat hukum adat di Desa Gayasan A memberikan persetujuan adanya sengketa waris yang pernah mereka amati atau bahkan alami sendiri, yang digambarkan sebagai berikut:

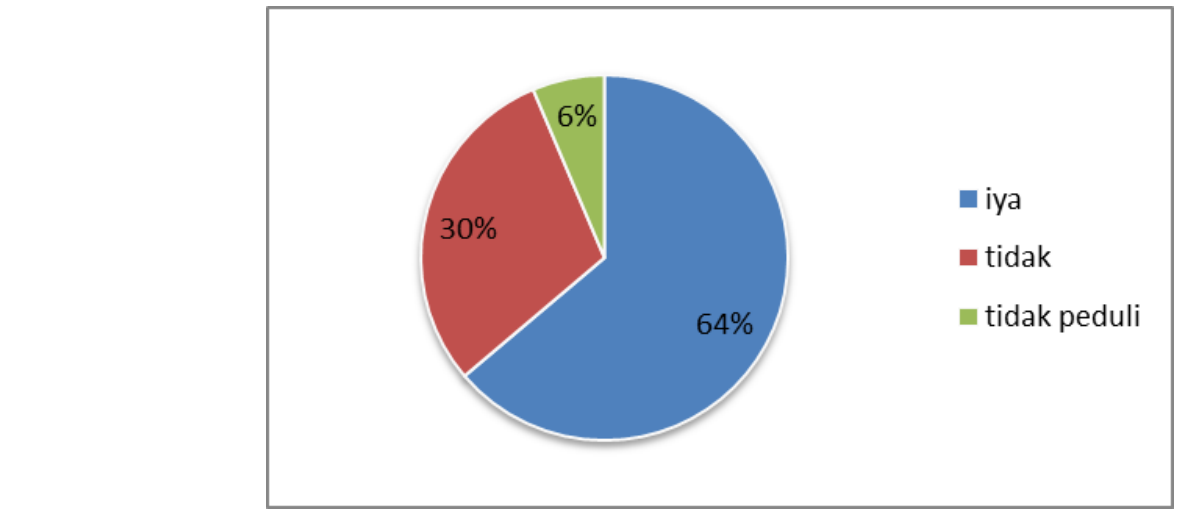

Gambar 1. Jumlah koresponden yang pernah mengamati maupun mengalami sengketa waris

Diagram diatas menunjukkan bahwa hasil Angket Koresponden dari 47 orang yang telah disetujui penggunaanya dalam konteks penelitian. Penyebaran angket dilakukan secara online melalui google form dengan mencakup sebanyak 9 pertanyan yang jawabannya diambil dari respon empiris koresponden terhadap pertanyaan seputar pembagian waris, persengketaan waris dan penyelesaian waris. Adanya angket ini sebagai penelusuran hukum adat khususnya hukum adat waris yang

\footnotetext{
${ }^{15}$ Wawancara bersama salah satu warga Desa Gayasan A, Kecamatan Jenggawah Kabupaten Jember yakni saudara Mukhtar Hafidz.
} 
berlaku di Desa Gayasan A, Kecamatan Jenggawah, Kabupaten Jember juga sebagai pengumpulan data tambahan yang mungkin terlewat dalam wawancara maupun observasi .

Mengingat perihal waris ini menyangkut masalah harta dan hubungan kerabat yang tidak dipungkiri merupakan kombinasi kedua hal yang sensitif untuk dibicarakan., sehingga ketidakpuasan para pihak yang tidak puas dengan pembagian waris memerlukan sarana penyelesaian alternatif yang menjadi karakter lokalitas masyarakat setempat dengan mengedepankan suatu kebijaksanaan, yang dinamakan dengan kearifan lokal. Sebagaimana Quaritch Wales yang merumuskan kearifan lokal atau local genius sebagai perkumpulan dari karakteristik budaya yang sebagian besar orang miliki sebagai hasil dari pengalaman mereka di awal kehidupan. Hal ini sesuai dengan yang diungkapkan oleh Abdullah bahwa kearifan lokal mengacu kepada berbagai kekayaan budaya yang tumbuh dan berkembang di dalam masyarakat yang diakui dan dipercayai keberadaannya sebagai sebuah elemen penting yang mampu mempertahankan sturuktur dasar sebuah masyarakat. ${ }^{16}$ Dari definisi diatas dapat kita ambil tiga pokok pikiran yakni kearifan lokal adalah karakter budaya yang merupakan identitas masyarakat, kelompok pemilik budaya sebagai subjek pelaksana dan pengalaman hidup yang lahir dari karakter budaya sebagai dasar untuk menentukan sikap dalam suatu permasalahan.

Kearifan lokal sendiri bentuknya beragam, ada yang tertulis maupun tidak tertulis. Dalam penelitian ini penulis lebih condong kepada kearifan lokal yang tidak tertulis yakni aturan secara lisan yang telah dijalankan secara turun temurun dan telah berkembang di dalam masyarakat hukum adat Desa Gayasan A, Kecamatan Jenggawah, Kabupaten Jember. Ada beberapa cara yang dilakukan oleh masyarakat hukum adat di Desa Gayasan A dalam menyelesaikan sengketa waris menurut kearifan lokal yang berlaku. Yakni, yang pertama adalah melalui diskusi internal di antara pihak yang bersengketa yang biasa di sebut rembugen, kemudian mediasi yang dilakukan oleh kepala adat, dan yang terakhir sanksi sosial berupa pengucilan (tak diajep) oleh masyarakat setempat yang diterapkan kepada pihak bersengketa yang menggunakan pemaksaan ataupun kekerasan di dalam proses penyelesaian sengketa.

\section{Penyelesaian Sengketa Waris melalui diskusi Internal di Antara Pihak yang Bersengketa (rembugen)}

Cara pertama yang dapat dilakukan, yang biasanya menjadi acuan awal dalam penyelesaian sengketa waris adalah melakukan diskusi dalam keluarga yang terkadang masih bersifat rahasia, sering kali disebut rembugen. Dalam diskusi ini anak yang paling tua ataupun pihak keluarga yang dianggap mampu biasanya memimpin jalan diskusi demi mendapatkan kesepakatan yang dirasa adil bagi semua pihak. Menurut salah satu warga cara ini merupakan cara yang terbaik dalam menyelesaikan

${ }^{16}$ Dikutip dalam Maria Matildis Banda, "Upaya Kearifan Lokal dalam Menghadapi Tantangan Perubahan Kebudayaan” Fakultas Ilmu Budaya Universitas Udayana, hlm. 1. 
suatu sengketa termasuk sengketa waris, karena masyarakat tidak tahu dan tidak dapat menyebarkan rumor aneh sekitar sengketa waris ini. ${ }^{17}$

Cara ini merupakan salah satu cara yang paling awal dari proses penyelesaian sengketa di Desa Gayasan A ini. Penggunaan diskusi internal di dalam keluarga memiliki kelebihan dan kekurangannya sendiri. Salah satu warga yang tidak ingin disebutkan namanya ${ }^{18}$ menuturkan diskusi internal (rembugen) dapat digunakan bila kedua belah pihak yang bersengketa hadir dan ikut berdiskusi dengan kepala dingin, artinya tidak ada unsur kekerasan ataupun intimidasi oleh salah satu pihak maupun keduanya. Namun diskusi internal (rembugen) tidak dapat menjadi upaya terakhir penyelesaian sengketa bila ada salah satu pihak yang terus-menerus berusaha menyuarakan pendapat tanpa mendengarkan pendapat pihak lain, hal ini mungkin malah berujung kepada terbelahnya pendapat sebuah keluarga menjadi pendukung diantara kedua belah pihak yang bersengketa.

Salah satu kasus sengketa waris yang pernah terselesaikan melalui diskusi internal (rembugen) adalah kasus dimana perantau yang sudah lama tidak pulang harus menerima fakta bahwa dirinya menerima bagian yang lebih sedikit daripada anggota keluarganya yang lain. Dirinya yang tinggal di perkotaan akan mencoba menggunakan rembugen sebagai cara menyelesaikan sengketa. Di dalam diskusi ini, pihak perantau akan mencoba meyakinkan anggota keluarga yang lain untuk memberikannya hak yang sesuai dengan hukum waris adat yang berlaku. Biasanya, bila tetap tidak diberikan perantau memilih untuk legowo ati dan menerima keputusan awal sebab tidak ingin menimbulkan keributan dalam keluarganya. Kasus ini merupakan salah satu kasus yang jarang terjadi, biasanya pihak yang meminta akan mencoba melakukan berbagai cara untuk mendapatkan keadilan dalam pembagian waris. Hal ini karena harta waris merupakan hal yang sensitif untuk dibicarakan sebab terkait dengan harta orang tua atau pewaris yang terkadang dianggap pilih kasih dalam pembagiannya.

Rembugen atau diskusi internal yang dilakukan oleh kedua belah pihak yang bersengketa dapat dilihat menganut tiga azas dalam hukum waris adat yang dikemukakan oleh Yulia, yakni azas pengendalian diri, azas kebersamaan hak, dan azas kekerabatan yang ketiganya merupakan elemen yang sangat penting dalam menyelesaikan sebuah persengeketaan waris. ${ }^{19}$ Azas pengendalian diri yang dimaksud adalah adanya pemikiran untuk menahan nafsu yang biasanya dikaitkan dengan ketaatan terhadap agama islam yang menjunjung perdamaian. Kemudian Azas kebersamaan hak yang menjadi inti dari adanya diskusi internal ini, yakni tujuan dari adanya diskusi ini adalah untuk mendapatkan keadilan dan kesamaan yang dalam pembagian waris. Dan yang terakhir adalah azas kekerabatan, yang

\footnotetext{
${ }^{17}$ Pengamatan langsung ke lapangan di Desa Gayasan A, Kecamatan Jenggawah, Jember

${ }^{18}$ Perlindungan nama informan dibutuhkan demi perlindungan terhadap pembicaraan oleh masyarakat yang masih menjadi salah satu kebiasaan di Desa Gayasan A, Kecamatan Jenggawah, Kabupaten Jember.

${ }^{19}$ Yulia, Op,cit.hlm.86.
} 
bermaksud agar adanya pemikiran bahwa sekali lagi, sengketa yang terjadi adalah di dalam internal kekeluargaan maka harus melihat faktor kelurge dibik tersebut jika ingin menginjak proses penyelesaian yang lebih jauh lagi.

Setelah itu, bila penyelesaian melalui diskusi internal atau rembugen ini dirasa tidak cukup atau malah menimbulkan keretakan di dalamnya, maka pihak keluarga yang bersengketa akan membutuhkan seorang mediator yang dalam hal ini adalah meminta kepala adat yang memimpin mediasi di antara kedua belah pihak yang bersengketa.

Penyelesaian Sengketa Waris melalui Mediasi yang dilakukan oleh Kepala Adat Desa Gayasan A, Kecamatan Jenggawah, Kabupaten Jember

Bila di dalam keluarga masih ada perselisihan dan belum disepakati perihal pembagian waris walaupun setelah melakukan perembugen, maka dilakukan mediasi. Secara etimologi mediasi berasal dari bahasa latin yakni mediare yang berarti berada di tengah. ${ }^{20}$ Makna ini menunjukkan pihak ketiga yang menjadi penengah atau pihak yang menjembatani pendapat dari dua belah pihak tanpa ada rasak keterkaitan dengan salah satunya.

Data menunjukkan sebanyak 53\% koresponden angket memberikan persetujuan terhadap penggunaan mediasi sebagai salah satu solusi serta penyelesaian akhir dalam menyelesaikan persengketaan waris. Hanya $25 \%$ dari koresponden menyatakan mediasi bukan sebagai jalan atau solusi terakhir dalam persengketaan waris. Sementara $22 \%$ ragu-ragu, hal ini karena koresponden tidak mengikuti persengketaan waris yang dialaminya secara detail maupun tidak pernah bersengketa waris. Sebagaimana digambarkan berikut ini:

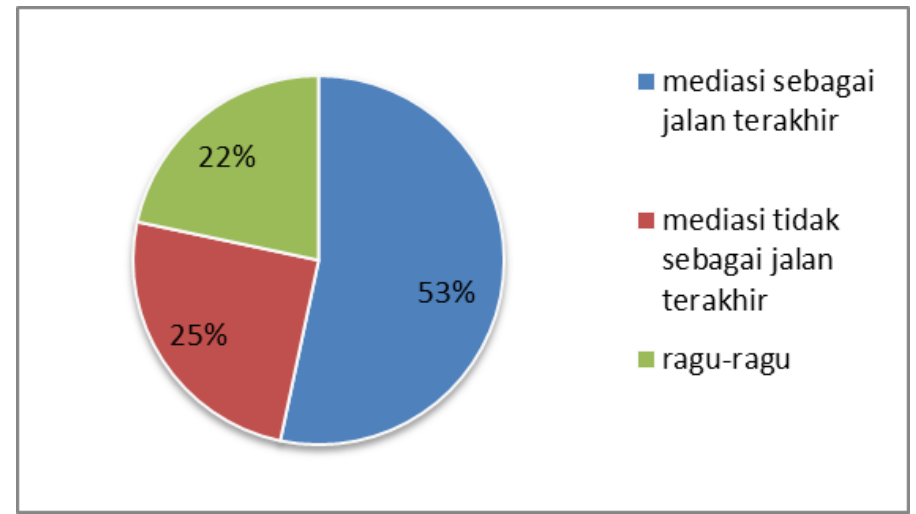

Gambar 2. Persetujuan koresponden mengenai mediasi sebagai penyelesaian akhir sengketa waris

Persetujuan koresponden mengenai mediasi dalam penyelesaian sengketa waris menujukkan bahwa kekuatan mediasi sebagaimana dikemukakan oleh Christopher

\footnotetext{
${ }^{20}$ Syahrizal Abbas, Mediasi dalam Perspektif Hukum Syariah, Hukum Adat dan Hukum Nasional, (Jakarta: Kencana, 2012), hlm.2
} 
W.Moore yakni "if the power of influence potencials of equal in strength, and recognized by all disputants, the mediator's job will $n$ be the assist the disputants in using their influence effectively to oroduce mutually sastisfactory results" 21 . Moore secara gamblang telah memberikan pendapatnya mengenai kekuatan dari pihak-pihak dalam mediasi sengketa waris yang apabila dikembangkan dengan baik serta pengaruh positif yang kuat dari mediator akan memberikan hasil keputusan yang dapat disepakati oleh semua pihak (win-win solution). Selain kekuatan berupa moral, hukum, politik serta sosial dari pihak-pihak dalam mediasi, kerahasiaan yang dijaga oleh mediator merupakan salah satu alasan untuk menjadikan mediasi sebagai langkah penyelesaian sengketa tanpa harus mengumumkannya ke khalayak publik seperti yang terjadi jika melewati jalur persidangan.

Sebanyak $25 \%$ dari 47 koresponden yang dihimpun dari masyarakat hukum adat di Desa GayasanA, Kecamatan Jenggawah, Kabupaten Jember tidak menjadikan mediasi oleh kepala adat sebagai penyelesaian akhir. Mereka melanjutkan persoalan mengenai waris ke muka persidangan, yang dianggap lebih pantas dalam menyelesaikan perkara yang mereka hadapi. Hal ini dikarenakan adanya rasa tidak puas oleh salah satu pihak atau bahkan kedua pihak dalam keputusan yang telah diusulkan oleh kepala adat. Selain itu juga, kurangnya rasa saling memahami dan keinginan pribadi untk mendapatkan harta waris yang paling adil menurut pandangan mereka sendiri merupakan salah satu alasan yang dikemukakan oleh salah satu warga yang pernah menjadi saksi dalam mediasi sengketa waris. ${ }^{22}$

Sementara itu, mengenai mekanisme penyelesaian mediasi yang ada di Desa Gayasan A Kecamatan Jenggawah dilakukan oleh kepala adat sebagai mediator dalam memberikan solusi. Menurut Soepomo kepala adat bapak dari suatu masyarakat yang menjadi pemimpin dari suatu pergaulan masyarakat. ${ }^{23}$ Karenanya kepala adat bertugas untuk memelihara hukum adat yang berlaku di tengah masyarakat agar hukum tersebut lestari dan tetap berjalan dengan efisien. Fungsi kepala adat sendiri tidak berbeda dengan hukum adat itu sendiri, kepala adat berfungsi untuk memberikan pedoman tingkah laku dalam masyarakat, menjaga keutuhan masyarakat hukum adat, memberikan pegangan agar tercipta suatu pengendalian sosial, memberikan kepastian hukum, serta merupakan tempat bersandarnya anggota masyarakat hukum adat utuk menjamin ketentraman dan menyelesaikan sebuah perkara. Soepomo kemudian melanjutkan, peran kepala adat dalam menjaga ketentraman dibuktikan dengan perannya menjadi hakim perdamaian yang berhak menimbang beratnya sanksi yang harus diberikan kepada pihak yang bersengketa, kepala adat disini dituntut menjadi pencipta perdamaian.

\footnotetext{
21 Dikutip oleh H.Ahmad, "Eksistensi dan Kekuatan Mediasi dalam Penyelesaian Sengketa Perdata di Pengadilan” (2014) istinbath', Jurnal hukum islam, hlm.78.

${ }^{22}$ Wawancara dengan salah satu warga yang pernah menjadi saksi dalam mediasi sengketa waris, beliau tidak ingin disebutkan namanya dan penulis menghormati keputusan tersebut. 23
} 
Hal tersebut dapat dilihat dalam perannya sebagai mediator dalam sebuah mediasi persengketaan khusunya persengketaan waris. ${ }^{24}$

Meskipun demikian, hasil mediasi yang dilakukan kepala adat dengan para pihak kadangkala menimbulkan ketidakpuasan terhadap solusi yang ditawarkan oleh kepala adat. Namun sekali lagi, mengingat adanya pengucilan terhadap pihak yang melakukan pemaksaan dan karena takut dibicarakan masyarakat maka dengan pasrah atau dalam bahasa jawanya "Legowo ati" beliau menerimanya. ${ }^{25}$ Kepala adat sendiri memiliki peran yang sangat berpengaruh terhadap keputusan salah satu pihak untuk legowo ati dan menerima keputusan awal. Biasanya kepala adat akan menjelaskan makna kekeluargaan yang lebih penting daripada harta, selain itu biasanya dibantu tokoh agama, kepala adat mampu membujuk pihak yang bersengketa untuk legowo ati terhadap keputusan awalnya. Kepala adat yang dipandang sebagai lambang kebijaksanaan berbarengan dengan tokoh agama merupakan senjata dalam mediasi agar berakhir dengan damai. ${ }^{26}$

Mediator sendiri merupakan pihak netral yang membantu para pihak dalam proses perundingan guna mencari berbagai kemungkinan penyelesaian sengketa tanpa menggunakan cara pemutus dan memaksakan sebuah penyelesaian. ${ }^{27}$ Mediator merupakan pendengar aktif yang bertjuan memperoleh pemahaman yang jelas dari perspektif kedua belah pihak. Mediator disini bekerja sama dengan kedua belah pihak yang bersengketa untuk membantu mereka memilih penyelesaian atauoun keputusan yang dapat menguntungkan salah satu pihak. Hal ini sesuai dengan pendapat Moore diatas. ${ }^{28}$

Mediator di dalam mediasi penyelesaian sengketa waris di Desa Gayasan A, Kecamatan Jenggawah, Kabupaten Jember yang akan kita bahas disini khususnya adalah kepala adat. Sebab kepala adat selain memiliki jabatan yang dianggap penting dan berpengaruh juga mempunyai kewenangan untuk menjadi penengah dalam mediasi bila diminta oleh keluarga yang bersengketa. Menurut hasil angket yang didata dari masyarakat hukum adat di desa Gayasan A, sebanyak 38.39\% koresponden mengatakan mediasi yang dilakukan tidak dilakukan oleh kepala adat namun menggunakan mediator lain seperti tokoh agama, kepala desa maupun tokoh masyarakat. Hal ini karena kepala adat kadang melimpahkan kekuasaanya pada mediator lain disebabkan kesibukan lain yang harus diurus oleh kepala adat desa Gayasan A. Namun tidak dapat dipungkiri, peran kepala adat menjadi mediator

\footnotetext{
${ }^{24}$ Maria D. Muga, "Peranan Kepala Adat dalam Penyelesaian Sengketa Tanah Ulayat melalui Mediasi (Studi Analaisa terhadap Penyelesaian Sengketa Tanah-Tanah Ulayat di Kecamtan SOA Kabupaten Ngada-FloresNusa Tenggara Timur) “(2008) Tesis Program Studi Magister Kenotariatan, Universitas Dipenogoro, hlm.4045 .

${ }^{25}$ Wawancara dengan salah satu warga yang pernah memiliki persengketaan perihal waris dan melakukan mediasi ke kepala Desa. Beliau menginginkan namanya dirahasiakan karena tidak ingin menjadi bahan pembicaraan masyarakat adat di Desa Gayasan A, Kecamatan Jenggawah, Kabupaten Jember tersebut.

${ }^{26}$ Obsevarsi mediasi sengketa waris.

${ }^{27}$ Op.cit. 
merupakan salah satu bentuk pelestarian kearifan lokal yang telah ada sejak lama dan dipergunakan oleh masyarakat hukum adat di desa Gayasan A, Kecamatan Jenggawah, Kabupaten Jember tersbeut. ${ }^{29}$

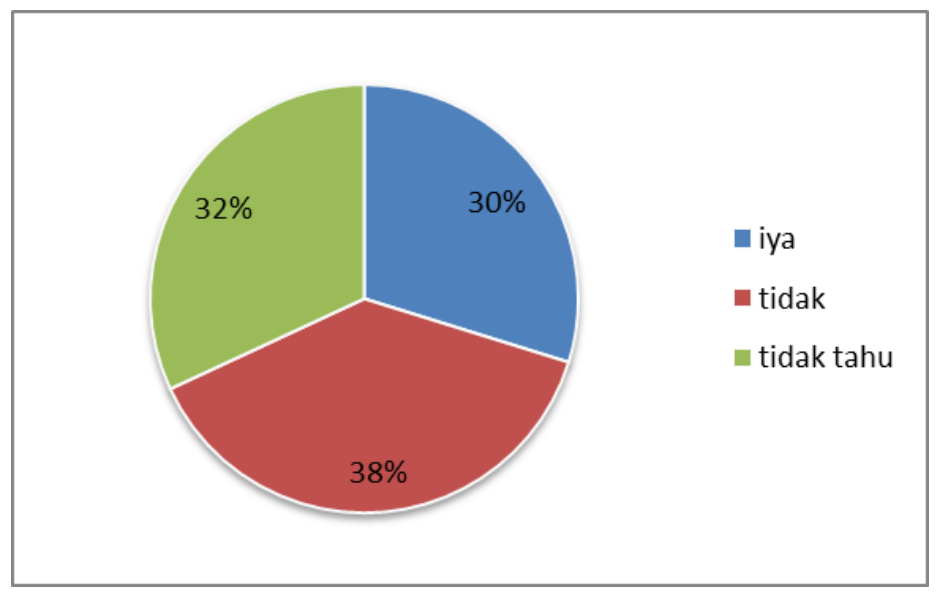

Gambar 3. Pernyataan koresponden mengenai kepala adat dalam penyelesaian sengketa waris

Di Desa ini, tata cara melakukan mediasi sebenarnya sederhana, yakni datang ke rumah kepala adat untuk meminta bantuan dengan niat baik-baik dan tanpa keributan. Biasanya, kedatangan perwakilan yang bersengketa ini akan dibarengi dengan membawa rokok, atau sekedar gula satu kilo sebagai tanda ramah tamah. Hal ini pun menjadi salah satu kearifan lokal yang masih dijunjung tinggi oleh masyarakat hukum adat di Desa Gayasan A, Kecamatan Jenggawah kabupaten Jember. Perilaku ini merupakan sebuah bentuk silaturahmi dan bukti kedekatan antara satu individu dengan individu lainnya.

Setelah diizinkan untuk masuk, kepala adat akan menyuguhkan secangkir kopi dan gorengan yang biasanya diberikan untuk mencairkan suasana. Agar antara kepala adat dan pihak yang bersengketa tidak ada rasa canggung atau macam keluargaen dibik sehingga merasa nyaman untuk berbicara dan berdiskusi atas masalah yang ada. setelahnya kepala adat mempersilahkan tamunya untuk menceritakan permasalahan apa yang sedang dihadapi dan dengan tujuan apa datang ke rumahnya. Kedatangan untuk meminta kepala adat untuk menjadi mediator pun harus melihat aspek waktu dan kesibukan kepala adat, karenanya biasanya mereka datang saat malam atau ketika kepala adat sedang berada dirumah.

Setelah berdiskusi mengenai masalah sengketa waris, kepala adat akan bertanya kepada perwakilan keluarga dari pihak yang bersengketa mengenai rembugen atau diskusi internal di dalam keluarganya. Setelah mendengarkan hasil rembugen dan memahami akar permasalahannya serta mengetahui tidak ada yang saling mengalah di antara kedua belah pihak yang terkait dalam persengketaan ini,

\footnotetext{
${ }^{29}$ Angket yang di isi oleh koresponden
} 
kepala adat akan menerima permintaan pihak yang bersengketa untuk menjadi mediator dalam mediasi. Masalah waktu dan tempat merupakan keputusan bersama antara keluarga yang sedang bersengketa dan kepala adat sebagai mediator, agar tidak ada yang beralasan untuk absen dari mediasi yang akan dilakukan. Biasanya, mediasi akan dilakukan di rumah salah satu pihak keluarga yang netral dalam persengketaan waris tersebut, namun tidak jarang juga dilakukan di salah satu rumah pihak yang bersengketa atapun di rumah kepala adat.

Ketika waktu dan tempat sudah ditentukan ada beberapa hal yang harus dijaga saat melakukan mediasi. Kesopanan tutur kata dan tingkah laku menjadi salah satu hal yang utama dalam mediasi yang akan dilakukan, mengingat kuatnya keyakinan pemeluk agama islam di desa ini tidak dapat dipungkiri akhlak merupakan salah satu hal yang paling terpenting dalam bermasyarakat. Kemudian pemahaman tentang waris yang di sengketa, sebab kepala adat walaupun merupakan mediator bukanlah yang ikut langsung dalam persengketaan sehingga membutuhkan referensi yang akurat sehingga dapat memberikan solusi yang terbaik pula. Kesadaran bahwa ini merupakan jalan perdamaian dan kepala desa hanyalah sebagai penengah bukan pembuat putusan akhir pun juga menjadi hal yang harus dipertimbangkan, sesuai dengan PERMA No.1 tahun 2008 mediator adalah pendengar yang tidak bisa ikut lebih dalam terhadap sebuah persengketaan dan merupakan penengah yang akan memberikan solusi dari mediasi yang sedang terjadi. ${ }^{30}$

Mediasi sengketa waris selain di ikuti oleh kedua belah pihak yang bersengketa juga harus di ikuti oleh sekurang-kurangnya setengah kekerabatan yang tahu langsung masalah sengketa waris. Keberadaan mereka selain menjadi saksi juga menjadi penjagaan bila ada sesuatu yang tidak di inginkan, seperti adanya unsur kekerasan maupun intimidasi salah satu pihak yang dirasa tidak etis dalam melakukan sebuah mediasi. Bila hanya kedua belah pihak saja yang mengikuti sebab tidak ingin diketahui oleh kerabat yang lain atau bahkan masyarakat, kepala adat sebagai mediator memperbolehkan. Disinilah tokoh agama yang memiliki pengaruh di Desa ini masuk menjadi saksi dan penjaga bila terjadi sesuatu yang tidak diiinginkan. Pemilihan tokoh agama sebagai saksi yang ikut adalah kesepakatan bersama antara mediator dan pihak yang bersengketa mengingat tokoh agama selain paham dengan waris, juga bijaksana dan memiliki perangai yang baik sehingga cocok menjadi reduce tension di antara pihak yang bersengketa ketika melakukan mediasi.

Setelah semua hadir, Mediator mempersilahkan satu pihak untuk menjelaskan duduk perkara menurut sudut pandangnya sendiri. Ketika sedang megungkapkan pendapat, tidak boleh di intervensi oleh pihak manapun bahkan mengintimidasi hingga ia selesai bicara. Setelahnya mediator mempersilahkan pihak satunya untuk menjelaskan dari sudut pandangnya. Kemudian setelah mendengarkan cerita dan duduk perkara dari sudut pandang kedua belah pihak yang bersengketa, kepala desa

\footnotetext{
${ }^{30}$ Peraturan Mahkamah Agung No.1 Tahun 2008 tentang Prosedur Mediasi di Pengadilan
} 
akan berdiskusi bersama dengan kerabat atau tokoh agama dalam menentukan sebuah solusi yang nanti akan ditawarkan.

Solusi yang ditawarkan oleh mediator setelah berdiskusi dengan kerabat ataupun tokoh agama sangat tergantung oleh keadaan pihak yang bersengketa. Bila keduanya tetap memaksakan kehendak maka solusi yang ditawarkan adalah harta warisan yang disengketakan biasanya akan dibagi menjadi dua diantara mereka. Dalam salah satu kasus yang jarang terjadi, yakni salah satu pihak yang bersengketa merasa sengketa ini harus cepat diselesaikan di forum mediasi tanpa harus berlanjut ke persidangan dan ia memilih untuk menerima keputusan yang "menyenangkan" pihak lain ataupun mundur dari statusnya sebagai ahli waris maka kepala desa dan kerabat atau tokoh agama mempersilahkan dengan hormat. Hal ini tentu berimbas pada sikap kerabat lain, jika salah satu pihak mengalah maka kerabat yang lain akan merasa pihak yang mengalah lebih mementingkan keluarga daripada keinginan untuk mendapatkan harta warisan sehingga kerabat lain biasanya akan merasa lebih hormat kepadanya. ${ }^{31}$

\section{Sanksi Pengucilan (tak diajepi) yang dilakukan masyarakat hukum adat Desa Gayasan A, Kecamatan Jenggawah terhadap pihak yang melakukan pemaksaan terhadap hak waris}

Persengketaan antara dua belah pihak terutama dalam hal yang sensitif seperti perihal waris merupakan hal yang dianggap tabu. Hal ini karena adanya anggapan oleh masyarakat setempat bahwa keluarga yang bersengketa akan menjadi tidak harmonis bahkan setelah persengketaan selesai. Masyarakat hukum adat yang tinggal di Desa Gayasan A ini sangat berpegang teguh pada asas kekerabatan yang sering kali menimbulkan sanksi adat berupa pengucilan atau sering disebut tak diajepi terhadap keluarga yang bersengketa khususnya kepada salah satu pihak yang dianggap melakukan intimidasi atau pemaksaan dalam sengketa waris tersebut.

Sanksi sendiri menurut Dewa Made Suartha berasal dari kata sanctum yang artinya adalah penegasan atau Bevestiging/Beckhractiging. Penegasan sendiri menurutnya ada yang positif dan ada pula yang negative, keberadaannya adalah sebagai perangsang dalam melakukan sesuatu ataupun tidak. Sanksi adat menurut I Made Widnyana memiliki tujuan untuk mengembalikan fungsi-fungsi kehidupan bermasyarakat yang menjadi tidak seimbang akibat adanya pelanggaran yang dilakukan. ${ }^{32}$

Mengenai macam sanksi adat, soepomo telah menjelaskan dalam bukunya "Bab-Bab tentang Hukum Adat" ada enam macam, yakni sanksi berupa pemaksaan untuk menikahi gadis yang dihamili di luar nikah, pembayaran denda, melakukan

\footnotetext{
${ }^{31}$ Pengamatan langsung melalui kasus-kasus sengketa waris yang ada di Desa Gayasan A, Kecamatan Jenggawah, Kabupaten Jember

${ }^{32}$ Ika Indah Yani, "Penerapan Sanksi dalam Delik Adat Silariang di Masyarakat Hukum Adat Kajang Kabupaten Bulukumba: Studi Kasus Hukum Adat kajang” (2016) Skripsi Fakultas Hukum Universitas Hasanuddin, Makassar, hlm.30-32
} 
aktifitas selamatan sebagai bentuk pembersihan hal ghaib, permintaan maaf, sanksi fisik dan yang terakhir adalah menjadikan pelaku sebagai orang asing atau lebih parah diusir dari masyarakat hukum adat. ${ }^{33}$ Tak diajepi yang dilakukan oleh masyarakat hukum adat di Desa gayasan A, Kecamatan Jenggawah, Kabupaten jember dapat dikatakan sebagai sanksi menjadikan pelaku sebagai orang asing yang telah dituturkan oleh Soepomo.

Alasan tak diajepi yang dilakukan masyarakat selain karena persengketaan namun juga mengarah bagaimana persengketaan itu diselesaikan. Penggunaan peradilan sebagai bentuk penyelesaian menjadi salah satu contoh alasan bagi masyarakat dusn Gayasan A untuk melakukan sanksi pengucilan. Hal ini serta merta bukanlah karena adanya rasa benci kepada penegakan hukum, namun lebih kepada pemikiran bahwa hubungan keluarga pihak yang bersengketa tentu akan lebih retak jika harus melewati jalur hukum. Karenanya bentuk sanksi berupa pengucilan ini diharapkan agar proses peradilan berhenti dan keluarga yang bersengketa dapat kembali berdamai seperti sebelumnya.

Penerapan sanksi ini secara tidak langsung sudah menjadi kearifan lokal yang dijunjung oleh masyarakat hukum adat desa Gayasan A. Efek yang terlihat pun cukup baik, karena rasa tidak ingin dianggap asing oleh masyarakat setempat akhirnya pihak yang bersengketa memutuskan untuk berdamai. Hal ini sejalan dengan pendapat yang dikemukakan oleh Hovland, Janis, dan Kelly, bahwa keinginan untuk tetap menjadi bagian dari kelompok merupakan motivasi dasar seseorang untuk memiliki kepatuhan hukum. ${ }^{34}$ Mengingat pendapat tersebut, hukum pengucilan (tak diajepi) terhadap pihak yang melakukan pemaksaan dalam sengketa waris menjadi suatu hal yang dapat berimbas pada proses sosial individu tersebut. karena itu sanksi tersebut dapat dianggap sebagai sanksi yang memiliki efek penghukuman yang cukup baik dalam kasus ini.

Bentuk pengucilan (tak diajepi) yang dilakukan oleh masyarakat hukum adat Desa Gayasan A, Kecamatan Jenggawah, kabupaten Jember biasanya berupa keengganan masyarakat untuk bergaul dengan orang ataupun keluarga yang terkena sanksi. Hal sederhana seperti tidak mengikutkan istri pihak yang bersengketa dalam acara rumpi atau bincang-bincang yang dilakukan oleh istri daerah tersebut yang biasanya dilakukan saat sedang memilah daun tembakau yang akan dijual, mengingat tembakau adalah salah satu varietas lokal yang menjadi salah satu penggerak roda ekonomi masyarakat Jember. Selain itu, dapat berupa tidak diundangnya pihak yang melakukan pemaksaan terhadap sengketa waris dalam adat selasaan yang secara rutin dilakukan setiap minggu di rumah salah satu warga. Serta yang paling akhir adalah bentuk pengucilan yang disertai oleh rumor dan gossip.

Dalam tulisan oleh Ralph L. Rosnow dan Eric K. Foster rumor di deskripsikan sebagai "public communications that are infused with private hypotheses about how the world

\footnotetext{
33 Ibid.

${ }^{34}$ Soerjono Soekanto, Op.cit,hlm.327.
} 
works or more specifically, ways of making sense to help us cope with anxieties and uncertainties." Lebih lanjut Rosnow dan Foster menyebut bahwa rumor memiliki tujuan tertentu yang dicapai dengan penyebaran rumor. Sementara Gosip menurut mereka "tends to have 'inner-circleness; about it, in that it is customarily passed between people .... But gossip is hardly inconsequential or without purpose". Pemaknaan gosip sebagai "small talk" yang disini dapat dilakukan oleh siapa saja menjadi salah satu alasan gosip dapat tersebar luas dengan cepat di tengah-tengah masyarakat. Dalam kasus pemaksaan di dalam Sengketa waris, penyebaran rumor memiliki tujuan untuk meminimalisir keretakan yang ada dan mendamaikan kedua pihak. Namun tak jarang, penyebaran rumor sesuai yang dikatakan rosnow memiliki aspek "ignored the emotional context of rumor" yang artinya terkadang dalam rumor yang tersebar dalam masyarakat malah akan membuat pihak yang bersengketa merasa terintimidasi dan tidak memungkinkan untuk melakukan perdamaian di antara mereka. ${ }^{35}$ Rumor dan gosip tentu tidak terlepas dari adanya kedekatan emosional salah satu pihak yang bersengketa, singkatnya semakin dekat pihak tersebut kepada masyarakat maka semakin baik pula rumor yang beredar begitu pula sebaliknya. Hal ini dikarenakan masyarakat akan mempertimbangkan kebaikan orang tersebut dan bagaimana ia bergaul dengan masyarakat hukum di Desa Gayasan A, Kecamatan Jenggawah, Kabupaten Jember ini.

Perbedaan Rumor dan gosip sebenarnya cukup mudah yakni wujud emosi personal yang terkandung di dalamnya. Jika rumor lebih kepada penyebaran kabar burung yang terkadang tidak memperhatikan kondisi emosional korbannya dan lebih kepada pengendalian masyarakat, gosip lebih kepada bagaimana kondisi emosional tersebut dapat tersalurkan melalui pembicaraan masyarakat pada umumnya. Karenanya untuk sanksi yang diberikan oleh masyarakat desa Gayasan A, Kecamatan Jenggawah, Kabupaten Jember berbarengan dengan adanya pengucilan lebih banyak di isi oleh gosip bukan rumor.

Dalam melaksanakan sanksi adat tak diajepi, masyarakat hukum adat di Desa Gayasan tidak sembarangan melakukan pengucilan terhadap seseorang. Ada beberapa pertimbangan yang sudah menjadi akar dari adanya sanksi ini, yakni kontrol masyarakat. Maksudnya kontrol masyarakat disini adalah mengenai bagaimana tingkah laku seseorang dapat mempengaruhi posisinya sebagai bagian dari masyarakat hukum adat. Seseorang yang dikucilkan biasanya menunjukkan sikap tidak beradab di hadapan masyarakat. Maksudnya disini adalah dalam sengketa waris, individu tersebut melakukan tindakan yang dianggap sebagian masyarakat tidak pantas atau tidak sesuai dengan adab di Desa Gayasan A, Kecamatan Jenggawah, Jember.

Salah satu contoh dari alasan pemberlakuan sanksi adat pengucilan atau tak diajepi adalah berkata kasar kepada pihak lain yang bersengketa. Walaupun mediasi

\footnotetext{
${ }^{35}$ Ralph L. Rosnow \& Eric K. Foster, “Rumor and Gossip Research” (2005) 19:4, hlm.1.
} 
dijalankan dengan rahasia atau diam-diam, jika salah satu pihak sering menggunakan kata kasar atau berwajah masam terhadap pihak lainnya maka tak dapat dipungkiri warga akan tahu siapalah yang kasar dalam persengketaan waris ini. Alasan lainnya adalah bila pewaris masih hidup namun salah satu pihak memaksakan kehendak untuk memiliki bagian yang lebih banyak. Adanya pemaksaan kepada pewaris oleh salah satu ahli waris tidak hanya dianggap sesuai dengan keinginan pewaris namun juga tidak beradab dan harus diberikan hukuman agar tersadar dan segera meminta maaf kepada pewaris yang biasanya adalah orang tua ahli waris. Terlebih lagi saat mediasi di hadapan kepala adat, jika ia menunjukkan sikap yang tidak sopan pada tetua maupun kerabat yang hadir di dalam mediasi dan memaksakan pendapatnya tanpa mendengarkan pendapat pihak lain, maka tentu akan dipandang buruk tidak hanya di mata kepala adat sebagai mediator namun di mata masyarakat hukum adat desa Gayasan A tersebut. Imbasnya adalah sanksi pengucilan atau tak diajepi seperti yang sudah dijelaskan di atas. ${ }^{36}$

Patut dipahami bahwa masyarakat yang tinggal di Desa Gayasan A, Kecamatan Jenggawah, Kabupaten Jember memiliki ikatan yang kuat antara satu individu dengan individu lainnya. Karena itu hukuman pengucilan ini dapat menjadi "rasa malu" tersendiri bagi individu yang dijatuhi hukuman tersebut. Terutama dalam penyebaran rumor dan gosip, individu yang digosipkan biasanya akan lebih mawas diri dan memperhatikan tingkah lakunya, tak jarang bahkan sampai meminta maaf dan menunjukkan perdamaiannya kepada masyarakat hukum adat di Desa Gayasan A. Bukti perdamaian biasanya terlihat dari bagaimana kedua pihak yang bersengketa tampak bercengkrama bersama, saling menyapa dan tak ada lagi tendensi ataupun ketegangan di antara keduanya.

Jadi ketika melihat efek yang ditimbulkan, hal ini sesuai dengan asumsi Mowrer yakni "if one identified with a force of which is afraid, one can no longer be hurt by it" 37 bahwa pemaksaan akan suatu hukuman terhadap seseorang ini bisa menjadi hal yang biasa di kehidupan individu tersebut, karena itu sebenarnya masyarakat yang melakukan pengucilan memberikan efek kontinous kepada individu yang dijatuhi hukuman untuk hidup sesuai dengan tatanan masyarakat. Hal ini tentu sangatlah riskan berubah menjadi sebuah intimidasi sosial yang menyebabkan salah satu individu yang dikucilkan (tak diajepi) merasa tidak pantas lagi untuk hidup ditengah bermasyarakat ataupun tidak nyaman dengan keadaan sekitarnya hingga memilih untuk pergi keluar desa ataupun pindah rumah, namun sekali lagi itu adalah hal yang sangat jarang terjadi mengingat keintiman diantara masyarakat hukum adat di Desa Gayasan A, Kecamatan Jenggawah, Kabupaten Jember tersebut.

\footnotetext{
${ }^{36}$ Pengamatan langsung di Desa Gayasan A, Kecamatan Jenggawah, Kabupaten Jember

${ }^{37}$ Soerjono Soekanto, Op.cit,hlm.329.
} 


\section{KESIMPULAN}

Kesimpulan yang dapat kita ambil dari pembahasan di atas adalah, pembagian waris di Dusun Gayasan A tidak terlepas dari penerapan sistem pluralisme hukum yang menempatkan hukum adat Madura yang notabene adalah asal sebagian besar masyarakat desa Gayasan A, kecamatan Jenggawah, Kabupaten Jember dan hukum islam sebagai agama mayoritas masyarakat setempat.. Namun, Terkadang ketika mengurusi perihal pembagian waris terjadi persengketaan yang tentu akan meretakkan hubungan kedua pihak yang bersengketa. Terutama karena adanya sistem kedekatan hubungan dengan pewaris yang bisa melwati batas status anak kandung maupun angkat, ataupun tidak setujunya ahli waris terhadap putusan pewaris yang didasarkan oleh pendapat masyarakat hukum adat. Keberadaan kearifan lokal mejadi Sarana alternatif yang strategis dalam menyelesaikan sengketa waris di desa Gayasan A Kecamatan Jenggawah, Kabupaten jember, yakni sebagai berikut: Pertama, diskusi internal keluarga (perembugen) yang biasanya dipimpin oleh anak tertua ataupun pihak keluarga yang netral dalam persengeketaan waris yang terjadi, Kedua, mediasi oleh kepala adat selaku mediator yang ditunjuk, mediasi sendiri biasanya akan berlangsung lebih formal dan khidmat, dari mediasi tersebut dapat menimbulkan dua solusi yang bisa dipilih oleh kedua belah pihak yang bersengketa, yakni mengalah dalam pembagian waris dan menerima keputusan awal di pembagian harta waris atau bila ingin menggunakan jalur hukum yang biasanya terjadi akibat tidak sampainya kemufakatan antara kedua belah pihak maka dipersilahkan untuk berlanjut ke pengadilan. Mediasi melalui kepala dusun sendiri harus disetujui oleh kedua belah pihak dan biasanya disaksikan oleh tokoh agama. Ketiga, sanksi adat berupa melakukan pengucilan (tak diajepi) terhadap pelaku yang melakukan pelanggaran, selain itu terkadang di sela-sela pemberlakuan sanksi berupa pengucilan (tak diajepi) biasanya akan tersebar rumor ataupun gosip mengenai pihak yang dianggap melanggar adab masyarakat hukum adat di Dusun Gayasan A, Kecamatan Jenggawah, Kabupaten Jember tersebut. Adanya sanksi adat ini sematamata agar pelaku medapatkan efek jera dan meminta maaf maupun berdamai dengan keluarganya sendiri serta mampu kembali ke tatanan masyarakat sebagai individu yang lebih baik lagi.

\section{DAFTAR PUSTAKA}

Abbas, Syahrizal Abbas. Mediasi dalam Perspektif Hukum Syariah, Hukum Adat dan Hukum Nasional, (Jakarta: Kencana, 2012).

Abdurrahmah, Draft laporan Pengkajian Hukum Tentang Mekanisme Pengakuan Masyarakat Adat (2015) Jakarta: kementrian Hukum dan Hak Asasi Manusia.

Ahmad, H. "Eksistensi dan Kekuatan Mediasi dalam Penyelesaian Sengketa Perdata di Pengadilan" (2014) istinbath', Jurnal hukum islam. 
Atlanta, Nur Nafa Maulida dkk. "Studi Komparasi Hak Waris dalam Hukum Adat dan Islam di Masyarakat Madura Pernatauan Desa Jelbuk, Kecamatan Jelbuk, Kabupaten Jember" (2018) 5: 3 Lentera Hukum, Universitas Jember.

Banda, Maria Maltidis. “Upaya Kearifan Lokal dalam menghadapi Tatangan Perubahan Kebudayaan." Fakultas Ilmu Budaya Universitas Udayana.

Harahap, Yahya. Kedudukan Janda, Duda, dan Anak Angkat dalam Hukum Adat, (Bandung: PT. Citra Aditya Bakti, 1993)

Hasanah, Sovia "Arti Teori eceptio A Contrario" 2018 < www.hukumonline.com > diakses pada tanggal 24 Agustus 2020.

Houker, M.B. Legal Pluralisme: an Introduction to Colonial and Neocolonial Laws (Offord: University Press, 1975)

Irmawati, "Teori Belah Bambu Syahrizal Abbas: antara Teori Reception in Complexeu, Teori Reciptie, dan Teori Receptio Contrario" (2017) 2:2, Ar Raniry.

Kementerian Perencanaan Pembangunan Nasional/ Badan Perencanaan Pembangunan Nasional, Masyarakat Adat di Indonesia: Menuju Perlindungan Sosial yang Inklusif (2013).

Moleong, Lexy J. Metode Penelitian Kualitatif (Bandung : PT Remaja Rosdakarya, 2010).

Muga, Maria D. "Peranan Kepala Adat dalam Penyelesaian Sengketa Tanah Ulayat melalui Mediasi (Studi Analaisa terhadap Penyelesaian Sengketa Tanah-Tanah Ulayat di Kecamtan SOA Kabupaten Ngada-Flores-Nusa Tenggara Timur) “(2008) Tesis Program Studi Magister Kenotariatan, Universitas Dipenogoro.

Nasution, Adelia. "Pluralisme Hukum Warsi di Indonesia" (2018) 5:1 Al-Qadha.

Ningrum, I Gusti Ayu Dian,dkk. "Penyelesaian Sengeketa Melalui Mediasi oleh Para Pihak di Pengadilan Negeri Denpasar dalam Perkara Perdata" Fakultas Hukum Universitas Udayana.

Nurcahyo, Hendra. Legal Standing Kesatuan Masyarakat Hukum Adat (Jakarta: Salemba Humanika, 2010)

Peraturan Mahkamah Agung No.1 Tahun 2008 tentang Prosedur Mediasi di Pengadilan.

Purba, Asmaul Husni "Faktor-Faktor Masyrakat Menyelesaikan Sengketa Warisan ke MUI Kota Medan" (2018) Skripsi Fakultas Syariah dan Hukum Universitas Agama Islam Negeri (UIN) Sumatera Utara.

Putusan M.A. tanggal 18 Maret 1959 Reg. No. 37 K/SIP/1959.

Rosnow,Ralph L. \& Eric K. Foster. “Rumor and Gossip Research” (2005) 19:4.

Soekanto, Soerjono. Hukum Adat Indonesia, (Jakarta: PT Raja Grafindo, 2013).

Taqwaddin. "Penguasaan Atas Pengelolaan Hutan Adat Oleh Masyarakat Hukum Adat (Mukim) di Provinsi Aceh" (2010) Disertasi Doktor Ilmu Hukum Universitas Sumatera Utara.

Thonthori, Jawahir. "Perlindungan dan Pengakuan Masyarakat Adat dan Tantangannya dalam Hukum Indonesia" (2013) 20:1 Jurnal Hukum IUS QUIA IUSTUM.

Yani, Ika Indah Yani. "Penerapan Sanksi dalam Delik Adat Silariang di Masyarakat Hukum Adat Kajang Kabupaten Bulukumba: Studi Kasus Hukum Adat kajang" (2016) Skripsi Fakultas Hukum Universitas Hasanuddin, Makassar.

Yulia, Buku Ajar Hukum Adat, (Lhokseumawe: Unimal Press,2016). 